\title{
Well-Aerated Southern Appalachian Forest Soils Demonstrate Significant Potential for Gaseous Nitrogen Loss
}

\author{
Peter Baas ${ }^{1,2, *}$, Jennifer D. Knoepp ${ }^{3}$ and Jacqueline E. Mohan ${ }^{1}$ \\ 1 Odum School of Ecology, University of Georgia, Athens, GA 30602, USA; jmohan@uga.edu \\ 2 Present Address: Natural Resource Ecology Laboratory, Colorado State University, \\ Fort Collins, CO 80523, USA \\ 3 Southern Research Station, Coweeta Hydrologic Laboratory, USDA Forest Service, Otto, NC 28763, USA; \\ jennifer.knoepp@usda.gov \\ * Correspondence: pbaas83@gmail.com; Tel.: +30-706-380-4492
}

Received: 23 October 2019; Accepted: 10 December 2019; Published: 17 December 2019

\begin{abstract}
Understanding the dominant soil nitrogen $(\mathrm{N})$ cycling processes in southern Appalachian forests is crucial for predicting ecosystem responses to changing $\mathrm{N}$ deposition and climate. The role of anaerobic nitrogen cycling processes in well-aerated soils has long been questioned, and recent $\mathrm{N}$ cycling research suggests it needs to be re-evaluated. We assessed gross and potential rates of soil $\mathrm{N}$ cycling processes, including mineralization, nitrification, denitrification, nitrifier denitrification, and dissimilatory nitrate reduction to ammonium (DNRA) in sites representing a vegetation and elevation gradient in the U.S. Department of Agriculture (USDA) Forest Service Experimental Forest, Coweeta Hydrologic Laboratory in southwestern North Carolina, USA. N cycling processes varied among sites, with gross mineralization and nitrification being greatest in high-elevation northern hardwood forests. Gaseous N losses via nitrifier denitrification were common in all ecosystems but were greatest in northern hardwood. Ecosystem $\mathrm{N}$ retention via DNRA (nitrification-produced $\mathrm{NO}_{3}$ reduced to $\mathrm{NH}_{4}$ ) ranged from $2 \%$ to $20 \%$ of the total nitrification and was highest in the mixed-oak forest. Our results suggest the potential for gaseous $\mathrm{N}$ losses through anaerobic processes (nitrifier denitrification) are prevalent in well-aerated forest soils and may play a key role in ecosystem $\mathrm{N}$ cycling.
\end{abstract}

Keywords: nitrogen cycling; DNRA; nitrifier denitrification; southern Appalachian Mountains; laboratory incubation

\section{Introduction}

Changing patterns of nitrogen $(\mathrm{N})$ deposition and climate are expected to dramatically alter ecosystem $\mathrm{N}$ and carbon (C) cycling. Nitrogen deposition [1-3], soil-warming-enhanced soil $\mathrm{N}$ mineralization [4,5], and increased $\mathrm{N}$ deposition in the southern Appalachian Mountains may potentially increase $\mathrm{N}$ concentrations in streams and rivers [4]. Increased $\mathrm{N}$ availability and higher temperatures could also result in greater forest productivity and increase the storage of atmospheric $\mathrm{C}$ in soil [6,7]. Additionally, greater reductions in moisture conditions in this ecosystem could affect forest productivity [8]. However, these gains could be reversed if the addition of labile $\mathrm{C}$ as leaf and root material results in enhanced respiration [9] and higher emissions of nitrous oxide, a potent greenhouse gas that is almost 300 times more effective than carbon dioxide at heating the atmosphere [10]. Recent studies have demonstrated the importance of anaerobic processes (e.g., denitrification and dissimilatory nitrate reduction to ammonium (DNRA)) in generally well-aerated soils [11], which are soils that are low in soil moisture and have no evidence of anaerobic conditions such as sulfate reduction, suggesting that to fully elucidate the effects of changing $\mathrm{N}$ deposition and temperature 
on southern Appalachian forest ecosystem function, we need to ascertain the dominant $\mathrm{N}$ cycling processes and the environmental parameters controlling their activity.

Net $\mathrm{N}$ mineralization and nitrification rates are often used as indicators of plant available $\mathrm{N}$ [12] and are generally correlated to forest productivity [13]. In the southern Appalachian Mountains, net $\mathrm{N}$ mineralization and nitrification rates are lower in mixed-oak-pine and low-elevation mixed-oak forest community types, relative to cove hardwood and northern hardwood forest communities [14,15]. Across sites, Knoepp and colleagues [14,16] found greater leaf litter inputs in forest types with greater rates of soil $\mathrm{N}$ cycling but not necessarily greater annual net primary productivity or rates of aboveground biomass accumulation. All sites had significant interactions between soil temperature and moisture affecting $\mathrm{N}$ cycling rates [17] and leaf $\mathrm{N}$ flux (i.e., greater $\mathrm{N}$ availability) [16]. A model by Bouwman et al. [18] estimated that soil denitrification $\left(\mathrm{N}_{2}\right.$ and $\left.\mathrm{N}_{2} \mathrm{O}\right)$ rates may account for $25 \%$ of all global gaseous $\mathrm{N}$ inputs $\left(\sim 90 \mathrm{Tg} \mathrm{N} \mathrm{y}^{-1}\right)$. Still, gaseous $\mathrm{N}$ losses from forest soils remain poorly defined $[19,20]$. Attempts to balance $\mathrm{N}$ budgets reveal a tight $\mathrm{N}$ cycle in low-N mixed-oak-pine forests (low rates of $\mathrm{N}$ mineralization, nitrification, and $\mathrm{N}$ leaching), while high-N northern hardwood forests exhibit leaky $\mathrm{N}$ cycling, with high rates of $\mathrm{N}$ mineralization, nitrification, and $\mathrm{N}$ leaching $[14,21]$. However, $\mathrm{N}$ budgets could not be reconciled, as high $\mathrm{N}$ soils mineralize more $\mathrm{N}$ than could be accounted for by plant uptake and leaching losses, while forests on lower- $\mathrm{N}$ soils take up more $\mathrm{N}$ than soils mineralize [21]. These results suggest that additional unmeasured $\mathrm{N}$ cycling processes play a key role in the fate of mineralized $\mathrm{N}$ in these forested ecosystems.

$\mathrm{N}$ cycling processes are often measured using net transformation rates; yet, net rates represent the final outcome of multiple competing processes often occurring simultaneously (Figure 1). The $\mathrm{N}$ cycle is complex with many oxidation and reduction steps that contribute to the depletion and/or accumulation of $\mathrm{N}$ in various pools (Figure 1). To mechanistically understand how the $\mathrm{N}$ cycle functions in an ecosystem, determinations of individual processes must be made. For example, soil $\mathrm{NH}_{4}$ is the by-product of the heterotrophic decomposition of organic matter $\mathrm{N}$ ( $\mathrm{N}$ ammonification) [22], as well as the less-studied chemoorganoheterotrophic DNRA [23] and assimilatory nitrate reduction to ammonium (ANRA) [24]. The correlation between gross and net rate assays is usually poor, making mechanistic conclusions based on net rates unreliable $[25,26]$. Nitrate reduction pathways, such as denitrification, DNRA, and ANRA, require anoxic conditions and were historically considered unimportant in well-aerated, nonwetland soils [23]. However, isotopic tracer methods have indicated that rates of denitrification [27] and DNRA $[11,27,28]$ in non-wetland soils can be substantial. We have only begun to elucidate the importance of nitrate reduction in well-aerated soils, such as those in the southern Appalachian Mountains. Here, N processing patterns are likely driven by spatially anoxic hot spots created by high soil moisture and soil respiration rates $[29,30]$ with the potential to process nitrate at rates significant at the ecosystem scale [19,31-33].

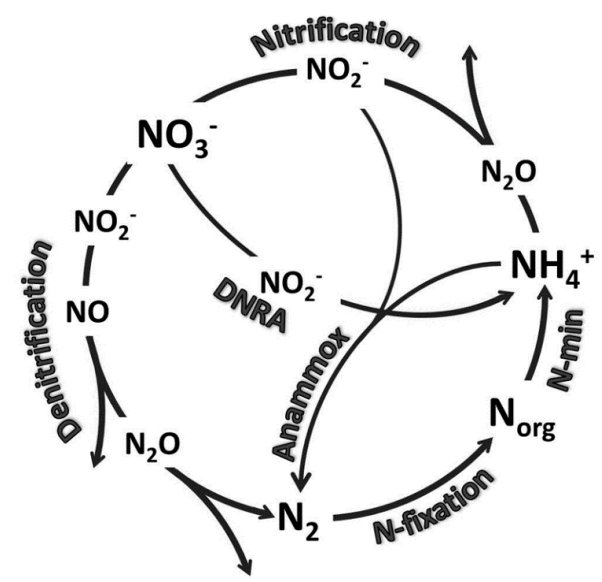

Figure 1. Conceptual representation of the nitrogen cycle. Arrows indicate the direction of transformations. $\mathrm{N}-\mathrm{min}=$ nitrogen mineralization. Adapted from Brandes et al. [34]. 
Our objective was to determine the relative importance of specific $\mathrm{N}$ cycling processes in four major forest types of the southern Appalachian Mountains using a combination of potential and gross $\mathrm{N}$ cycling assays. We hypothesized (1) that sites with high $\mathrm{N}$ availability (cove hardwood and northern hardwood forests) would exhibit the greatest rates of gaseous $\mathrm{N}$ losses and that these rates explain a substantial proportion of currently unaccounted for $\mathrm{N}$ losses, and (2) that the importance of DNRA is greater in sites with high $\mathrm{C}$ availability (low $\mathrm{C}: \mathrm{N}$; northern hardwood) and lower in sites with low $\mathrm{C}$ availability (high C:N; mixed-oak-pine and mixed-oak sites).

\section{Methods}

\subsection{Site Description}

This study was conducted at Coweeta Hydrologic Laboratory, a U.S. Department of Agriculture (USDA) Forest Service experimental forest and a National-Science-Foundation-funded Long-Term Ecological Research (LTER) site in the southern Appalachian Mountains of western North Carolina. The average temperatures in Coweeta range from $20^{\circ} \mathrm{C}$ midsummer (June-August) to $5^{\circ} \mathrm{C}$ midwinter (December-January), with an annual average precipitation of $1900 \mathrm{~mm}$. The growing season extends from May through September and receives an average precipitation of $800 \mathrm{~mm}$ of precipitation [35,36].

The study was conducted in four large $80 \times 80 \mathrm{~m}$ plots established along the elevation and vegetation gradient within the Coweeta basin in 1991. All sites are located in reference watersheds (undisturbed since 1927) and include the four major vegetation types present in the southern Appalachians, including xeric mixed-oak-pine, mesic cove hardwood, mesic mixed-oak, and mesic northern hardwood forests [37,38]. Soils are predominately in the Ultisols and Inceptisols orders and have profiles characterized by a well-developed mull-type O-horizon (Oa-horizon of $2-4 \mathrm{~cm}$ ), A horizon (7-22 cm), transitional horizon (AB or BA; $10-20 \mathrm{~cm}$ ), and a clay accumulation layer (Bt or Bw; $30-40 \mathrm{~cm}$ ) with total soil pedon depth ranging from 60 to $100 \mathrm{~cm}$ [39]. Table 1 contains more detailed climatic, vegetation and soils information.

Table 1. Detailed climatic, vegetation, and soil information. Selected site characteristics. Data compiled from Coweeta Long-Term Ecological Research (LTER) Program records. See website [40] for additional information. Modified from [15], and mean annual temperature and precipitation data are from [16].

\begin{tabular}{|c|c|c|c|c|}
\hline Site & Mixed Oak-Pine & Cove Hardwood & Mixed Oak & Northern Hardwood \\
\hline $\begin{array}{l}\text { Geographic } \\
\text { Coordinates }\end{array}$ & $83^{\circ} 26^{\prime} \mathrm{N}, 35^{\circ} 3^{\prime} \mathrm{W}$ & $83^{\circ} 26^{\prime} \mathrm{N}, 35^{\circ} 2^{\prime} \mathrm{W}$ & $83^{\circ} 26^{\prime} \mathrm{N}, 35^{\circ} 2^{\prime} \mathrm{W}$ & $83^{\circ} 27^{\prime} \mathrm{N}, 35^{\circ} 1^{\prime} \mathrm{W}$ \\
\hline Elevation (m) & 788 & 801 & 860 & 1389 \\
\hline Precipitation $(\mathrm{cm})$ & 187 & 189 & 191 & 238 \\
\hline Temperature $\left({ }^{\circ} \mathrm{C}\right)$ & 12.9 & 12.3 & 12.7 & 9.6 \\
\hline Aspect (degrees) & 180 & 340 & 15 & 20 \\
\hline Slope (degrees) & 34 & 21 & 34 & 33 \\
\hline Vegetation & Oak-pine & Cove hardwood & Mixed oak & Northern hardwood \\
\hline Dominant Species & $\begin{array}{c}\text { Pinus rigada, Quercus } \\
\text { montana, Quercus prinus, } \\
\text { Carya spp., Kalmia latifola }\end{array}$ & $\begin{array}{c}\text { Liriodendron } \\
\text { tulipifera, Quercus } \\
\text { montana, Carya spp. }\end{array}$ & $\begin{array}{l}\text { Quercus montana, Carya } \\
\text { spp., Quercus rubra, } \\
\text { Rhododendron maximum }\end{array}$ & $\begin{array}{c}\text { Betula allegheniensis, } \\
\text { Quercus rubra, Betula } \\
\text { lenta, Tilia heterophylla }\end{array}$ \\
\hline Moisture Regime & Xeric & Mesic & Mesic & Mesic \\
\hline Soil Series & $\begin{array}{l}\text { Evard/Cowee Chandler } \\
\text { Edneyville/Chestnut }\end{array}$ & $\begin{array}{c}\text { Saunook } \\
\text { Tuckaseegee }\end{array}$ & Trimont & Sitet \\
\hline Soil Texture & $\begin{array}{l}\text { Fine-loamy, } \\
\text { Coarse-loamy, } \\
\text { Coarse-loamy }\end{array}$ & $\begin{array}{l}\text { Fine-loamy, } \\
\text { Fine-loamy }\end{array}$ & Fine-loamy & Coarse-loamy \\
\hline Soil Subgroup & $\begin{array}{c}\text { Typic Hapludults, Typic } \\
\text { Dystrudepts }\end{array}$ & $\begin{array}{l}\text { Humic Hapludults, } \\
\text { Typic Dystrudepts }\end{array}$ & Humic Hapludults & Typic Humudepts \\
\hline
\end{tabular}




\subsection{Sample Collection}

We collected organic and mineral soil layers for use in laboratory determination of potential $\mathrm{N}$ cycling processes five times over 16 months (November 2010, March 2011, June 2011, November 2011, and March 2012). Soils (O-horizon and 0-15 cm mineral soil) were collected using a stainless-steel ( $2.5 \mathrm{~cm}$ inside diameter) corer $(n=6$; except for November 2012, when $n=3$ ) sieved to $<2 \mathrm{~mm}$ and subdivided for laboratory assays. We determined potential nitrification and denitrification rates to assess temporal dynamics. We also collected soils from the most active part of the soil horizon $\left(0-10 \mathrm{~cm}\right.$ mineral soil) in May 2012 to measure gross $\mathrm{N}$ cycling rates using ${ }^{15} \mathrm{~N}$ isotopically labeled $\mathrm{NO}_{3}$ and $\mathrm{NH}_{4}$. Samples used for potential nitrification assays were stored at room temperature for $<72 \mathrm{~h}$ and denitrification samples were stored at $4{ }^{\circ} \mathrm{C}$ for $<2$ weeks before conducting the assays. Samples collected for ${ }^{15} \mathrm{~N}$ gross assays were stored at room-temperature conditions and assays were conducted within $48 \mathrm{~h}$ of collection.

\subsection{Nitrogen Cycling: Potential Rates}

Potential nitrification and denitrification rates were determined using a modified slurry approach [32,41]. Nitrification was determined using $5 \mathrm{~g}$ of organic or mineral soil, mixed with $15 \mathrm{~mL}$ of media $\left(2.5 \mathrm{mM}\left(\mathrm{NH}_{4}\right)_{2} \mathrm{SO}_{4}, 0.80 \mathrm{mM} \mathrm{K}_{2} \mathrm{HPO}_{4}\right.$, and $\left.0.20 \mathrm{mM} \mathrm{KH}_{2} \mathrm{PO}_{4}\right)$ and incubated on a shaker at $150 \mathrm{rpm}$ and $25{ }^{\circ} \mathrm{C}$ to maintain oxic conditions. Subsamples $(1 \mathrm{~mL})$ of the soil/media slurry were collected at $0.5,2.0,6.0-8.0$, and $24.0 \mathrm{~h}$ for $\mathrm{NO}_{\mathrm{x}}$ analysis using colorimetric methods [42]. Potential denitrification rates were determined using the acetylene block method [43]. Five grams of soil ( $2 \mathrm{~g}$ for O-horizon) were mixed with $5 \mathrm{~mL}$ of media ( $1 \mathrm{mM}$ dextrose and $1 \mathrm{mM}$ nitrate), purged with He for $30 \mathrm{~min}$, and placed in a $30 \mathrm{~mL}$ serum vial. Ten percent of the headspace volume was displaced with acetylene. The soil/media slurry was shaken at $150 \mathrm{rpm}$ and $25^{\circ} \mathrm{C}$, and the head space $(1 \mathrm{~mL})$ was subsampled at $0,2.0$, and $6.0 \mathrm{~h}$ for $\mathrm{N}_{2} \mathrm{O}$ analysis using a GC-ECD (Shimadzu Inc., Tokyo, Japan).

\subsection{Nitrogen Cycling: Gross Rates}

We measured gross rates of $\mathrm{N}$ mineralization (i.e., ammonification), nitrification, nitrifier denitrification (reduction of ammonia to $\mathrm{N}_{2}$ ), and DNRA using laboratory ${ }^{15} \mathrm{~N}$ tracer approaches and analysis of the ${ }^{15} \mathrm{~N}$ content of the microbial biomass [44,45]. We composited soil samples collected in May $2013(n=4)$ by site into a single sample for gross $\mathrm{N}$ analysis, and samples were sieved together to ensure complete mixing. Thirty grams of each composited soil sample were extracted using $100 \mathrm{~mL}$ of $2 \mathrm{M} \mathrm{KCl}$ to determine initial $\mathrm{NO}_{3}$ and $\mathrm{NH}_{4}-\mathrm{N}$ content and natural ${ }^{15} \mathrm{~N}$ abundance. To determine initial microbial biomass $\mathrm{N}$ and ${ }^{15} \mathrm{~N}, 10 \mathrm{~g}$ of soil was extracted with $80 \mathrm{~mL}$ of $0.5 \mathrm{M} \mathrm{K}_{2} \mathrm{SO}_{4}$ and a second $10 \mathrm{~g}$ sample was fumigated with ethanol-free chloroform, incubated for 5 days, then extracted with $0.5 \mathrm{M}$ $\mathrm{K}_{2} \mathrm{SO}_{4}[45,46]$. The remaining composited sample was divided in two (approximately $300 \mathrm{~g}$ each) for use in ${ }^{15} \mathrm{NO}_{3}$ and ${ }^{15} \mathrm{NH}_{4}$ labeling experiments. We calculated site-specific label enrichment additions equal to $20 \%$ of extractable $\mathrm{NO}_{3}$ and $\mathrm{NH}_{4}$ to minimize fertilization artifacts [11]. One sample was labeled with $\mathrm{NO}_{3}\left(3.8 \% \pm 2.3 \% \mathrm{~K}^{15} \mathrm{NO}_{3}(98 \%)\right)$ in the amounts of mixed oak-pine, $4.1 \times 10^{-5} \mathrm{mg}$ ${ }^{15} \mathrm{~N} \mathrm{~kg}_{\text {soil }}{ }^{-1}$; cove hardwood, $3.4 \times 10^{-5} \mathrm{mg}^{15} \mathrm{~N} \mathrm{~kg}_{\text {soi }} \mathrm{l}^{-1}$; mixed-oak low, $2.6 \times 10^{-5} \mathrm{mg}^{15} \mathrm{~N} \mathrm{~kg}_{\text {soil }}{ }^{-1}$; and northern hardwood, $2.5 \times 10^{-2} \mathrm{mg}^{15} \mathrm{~N} \mathrm{~kg}_{\text {soil }}{ }^{-1}$. The second sample was labeled with $\mathrm{NH}_{4}$ $\left(\left({ }^{15} \mathrm{NH}_{4}\right)_{2} \mathrm{SO}_{4}(98 \%)\right)$ at the following rates: mixed oak-pine, $0.16 \mathrm{mg}{ }^{15} \mathrm{~N} \mathrm{~kg}_{\text {soil }}{ }^{-1}$; cove hardwood, $0.21 \mathrm{mg}^{15} \mathrm{~N} \mathrm{~kg}_{\text {soil }}{ }^{-1}$; mixed-oak low, $0.06 \mathrm{mg}^{15} \mathrm{~N} \mathrm{~kg}_{\text {soil }}{ }^{-1}$; and northern hardwood, $0.33 \mathrm{mg}^{15} \mathrm{~N} \mathrm{~kg}_{\text {soil }}{ }^{-1}$. Following thorough mixing, $50 \mathrm{~g}$ of each isotopically labeled soil sample was placed in $1 \mathrm{~L}$ Mason jars (six replicate jars per composited soil sample). The jars were sealed with lids adapted with a septum for gas sampling purposes and incubated under field moisture conditions (ranging from $31 \%$ to $68 \%$ gravimetric soil moisture) at $20^{\circ} \mathrm{C}$. At each sample collection, we randomly selected three replicate sample jars to subsample. From the ${ }^{15} \mathrm{NH}_{4}$-labeled jars, we collected two $9 \mathrm{~mL}$ gas samples for $\mathrm{N}_{2}$ and $\mathrm{N}_{2} \mathrm{O}$ concentrations and isotopic analysis $\left({ }^{15} \mathrm{~N}_{2} \mathrm{O}\right.$ and $\left.{ }^{15} \mathrm{~N}_{2}\right)$ after 4 and $24 \mathrm{~h}$ of incubation. Gas samples were stored in Labco Exetainers (Labco Limited Inc., Ceredigion, UK) at room temperature until 
analysis. After the gas sample collection, $20 \mathrm{~g}$ of soil from each incubated jar $\left(\mathrm{NO}_{3}\right.$ - and $\mathrm{NH}_{4}$-labeled) was extracted with $100 \mathrm{~mL}$ of $2 \mathrm{M} \mathrm{KCl}$ to determine $\mathrm{NH}_{4}$ and $\mathrm{NO}_{3}$ concentrations and their ${ }^{15} \mathrm{~N}$ relative abundance in these specific inorganic nitrogen species. To estimate microbial biomass nitrogen (MBN) and ${ }^{15} \mathrm{~N}, 10 \mathrm{~g}$ of soil was extracted with $80 \mathrm{~mL}$ of $0.5 \mathrm{M} \mathrm{K}_{2} \mathrm{SO}_{4}$, and another $10 \mathrm{~g}$ was fumigated with ethanol-free chloroform for 5 days and subsequently extracted with $0.5 \mathrm{M} \mathrm{K}_{2} \mathrm{SO}_{4}$ according to Cabrera and Beare [46] and Silver et al. [45]. We used the difference between the nonfumigated and fumigated extractions to calculate microbial biomass, total microbial $\mathrm{N}$, and microbial ${ }^{15} \mathrm{~N}$ uptake.

\subsection{Carbon Processing}

Labile carbon (LC) and potential denitrification were determined for the soil samples composited as previously described. LC was assessed using potential $\mathrm{C}$ mineralization incubations under anoxic $\left(\mathrm{LC}_{\text {anoxic }}\right)$ and oxic $\left(\mathrm{LC}_{\text {oxic }}\right)$ conditions via a modified potential soil respiration method [47]. Five grams of field moist composited soil were weighed into six $50 \mathrm{~mL}$ centrifuge tubes fitted with septa for gas sampling. Soils were adjusted to 50\% gravimetric soil moisture with deionized water. Half of the tubes $(n=3)$ were purged with He for $1 \mathrm{~min}$ to assure anoxic conditions and half $(n=3)$ were purged with $\mathrm{CO}_{2}$-free air for $1 \mathrm{~min}$ to represent ambient oxygen conditions. Soils were incubated at $25^{\circ} \mathrm{C}$ and $1 \mathrm{~mL}$ gas samples were taken $0.5,4$, and $24 \mathrm{~h}$ after capping the centrifuge tubes. Gas samples were immediately analyzed for $\mathrm{CO}_{2}$ content using a LICOR LI-7000 setup for small volume injections. Potential respiration rates in $\mu \mathrm{g} \mathrm{C} \mathrm{g}_{\text {soil }}{ }^{-1} \mathrm{~d}^{-1}$ were determined by regression analysis. Potential denitrification rates were assessed as described earlier.

\subsection{Soil Chemical, $N$, and ${ }^{15} N$ Analyses}

Concentrations of $\mathrm{NH}_{4}, \mathrm{NO}_{3}$, and $\mathrm{NO}_{2}$ were determined colorimetrically on $\mathrm{KCl}$ extracts $[42,48]$ using an AlpKem model 3590 Autoanalyzer (OI Analytical, College Station, TX, USA). Soil total carbon was determined using near-infrared reflectance spectroscopy (NIRS) techniques as described in Baas et al. [32]. Microbial biomass was determined as the difference between pre- and postfumigated $\mathrm{K}_{2} \mathrm{SO}_{4}$ extracts analyzed for dissolved organic carbon (DOC) using a total carbon analyzer (Shimadzu TOC- $\mathrm{V}_{\mathrm{CPH}} \mathrm{TNM}$ ). MBN was determined by persulfate digestion and colorimetric analysis of $\mathrm{NO}_{3}$ of the $\mathrm{K}_{2} \mathrm{SO}_{4}$ extract [46]. Soil extracts were prepared for isotopic analysis using the diffusion method to capture both ammonium and nitrate (after reduction by Devarda's alloy), in which solutions were alkalized and the volatilized ammonia was trapped on an acidified filter. Nitrogen isotopic ratios of the trapped $\mathrm{N}$ were determined using a PDZ Europa ANCA-GSL elemental analyzer interfaced to a PDZ Europa 20-20 isotope ratio mass spectrometer (Sercon Ltd., Cheshire, UK) at the University of California, Davis Isotope Facility. $\mathrm{N}_{2} \mathrm{O}$ concentrations were determined using a gas chromatograph coupled to an electron capture detector ( ${ }^{63} \mathrm{Ni}$ ) (Shimadzu GC-14A). Gaseous isotopic ratios $\left(\mathrm{N}_{2} \mathrm{O}\right.$ and $\left.\mathrm{N}_{2}\right)$ were determined using a ThermoFinnigan GasBench with a PreCon trace gas concentration system interfaced to a ThermoScientific Delta V Plus isotope-ratio mass spectrometer (Precon-IRMS, Bremen, Germany) at the University of California, Davis Isotope Facility.

Nitrogen cycling rates calculated for the different potential and gross processes were calculated as described below and are summarized in Table 2. Potential net nitrification and denitrification rates were calculated using $\mathrm{t}=0$ and $\mathrm{t}=24 \mathrm{~h}$ measurements of nitrate and $\mathrm{N}_{2} \mathrm{O}$, respectively, and are reported as $\mu \mathrm{g} \mathrm{kg}_{\text {soil }}{ }^{-1} \mathrm{~h}^{-1}$ and in $\mathrm{mg} \mathrm{N} \mathrm{m}^{-2} \mathrm{~d}^{-1}$ using bulk densities previously determined for each site [32]. Gross nitrogen cycling $\mathrm{N}$ mineralization, nitrification, $\mathrm{NH}_{4}{ }^{+}$, and $\mathrm{NO}_{3}{ }^{-}$consumption rates were calculated based on isotope pool dilution and are reported as $\mu \mathrm{g} \mathrm{N} \mathrm{g}_{\text {soil }}{ }^{-1} \mathrm{~d}^{-1}[44,49]$. Gross DNRA was calculated from the ${ }^{15} \mathrm{NO}_{3}{ }^{-}$-labeled soil incubations as the difference in $2 \mathrm{M} \mathrm{KCl}$ extractable $\mathrm{NH}_{4}$ between $t=0$ and $t=24 \mathrm{~h}$, corrected for the mean residence time (MRT) and divided by the average $\mathrm{NO}_{3}$ pool atom $\%{ }^{15} \mathrm{~N}$ excess [27,45]. We used the ${ }^{15} \mathrm{NH}_{4}$-labeled soils (nitrifier denitrification) to measure $\mathrm{N}_{2}$ and $\mathrm{N}_{2} \mathrm{O}$ production during the $24 \mathrm{~h}$ incubation period, calculated as ${ }^{15} \mathrm{~N}_{2}$ and ${ }^{15} \mathrm{~N}_{2} \mathrm{O}$ production divided by the average $\mathrm{NH}_{4}$ atom $\%{ }^{15} \mathrm{~N}$ excess [27]. Microbial biomass was calculated as fumigated minus nonfumigated DOC from the $\mathrm{K}_{2} \mathrm{SO}_{4}$ extracts with the efficiency correction factor of 0.45 [50]. 
Microbial biomass $\mathrm{N}$ was calculated as the difference between fumigated and nonfumigated total $\mathrm{N}$ in the $\mathrm{K}_{2} \mathrm{SO}_{4}$ extract with the efficiency correction factor of 0.54 [51].

Table 2. Summary of data utilized for calculating potential or gross nitrogen cycling rate. For more details on specific experimental procedures, see methods section.

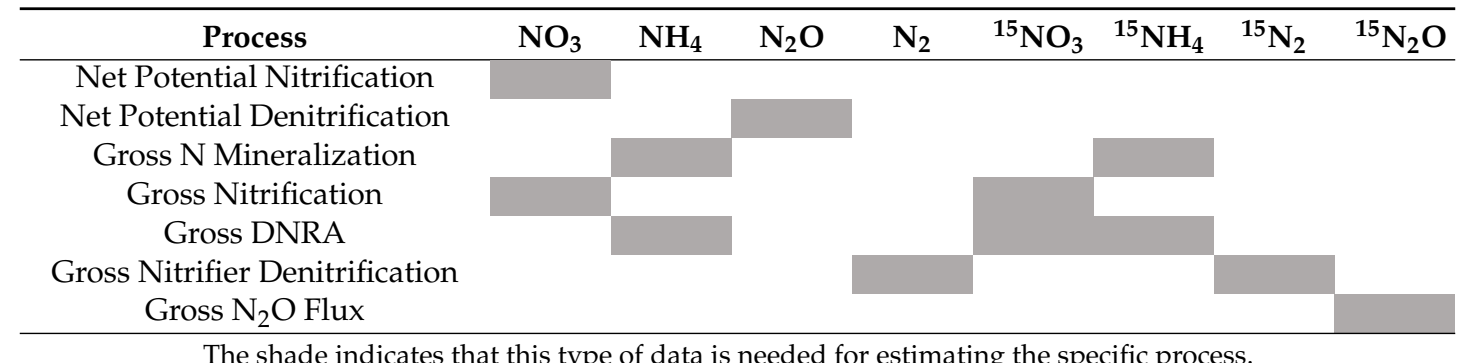

\subsection{Statistical Procedures}

We tested for differences in potential nitrogen cycling among sites using a mixed model approach with sample date and site as fixed effects. If a significant interaction between date and site was detected, differences between sites were analyzed at each sample date and differences between sample dates were analyzed for each site. We used a one-way ANOVA to test for differences among sites for gross $\mathrm{N}$ cycling rates, $\mathrm{N}_{2}$ and $\mathrm{N}_{2} \mathrm{O}$ flux rates, $\mathrm{C}$ mineralization rates, and microbial biomass $(\mathrm{C}$ and $\mathrm{N}$ ). Data were log-transformed as necessary to meet ANOVA assumptions of normal distribution, which was confirmed using the goodness-of-fit function in JMP. All variability errors are presented by the standard error of the mean unless specified. We used linear regression analysis to investigate relationships between gross nitrogen cycling processes and potential respiration and potential denitrification rates. The northern hardwood site differed significantly from other sites in process rate measurements and organic matter concentrations [16], predicting different potential process drivers in this site. Therefore, we conducted additional tests of the relationships between $\mathrm{N}$ cycling processes excluding this site. Statistical analyses were conducted using JMP 11.0 (SAS Institute Inc., Cary, NC, USA). Significant effects are reported at $p<0.05$ unless stated otherwise.

\section{Results}

\subsection{Nitrogen Cycling}

Gross nitrogen transformation rates, including $\mathrm{N}$ mineralization, nitrification, DNRA, nitrifier denitrification, and $\mathrm{N}_{2} \mathrm{O}$ production, were determined in May 2012 (Table 3), as well as potential nitrification and potential denitrification from November 2010 through March 2012 (Figure 2). Gross N mineralization rates varied among sites and were greater in northern hardwood compared with mixed oak and mixed oak-pine $\left(F_{3,8}=7.2, p=0.01\right)$, while gross nitrification $\left(F_{3,8}=7.2, p=0.001\right)$ rates were greater in northern hardwood compared with all other sites. DNRA rates were greater in northern hardwood compared with mixed oak-pine $\left(F_{3,8}=19.2, p<0.001\right)$. The percent of nitrate produced from nitrification that was reduced by DNRA was greater in mixed oak (20\%) compared with northern hardwood $(2 \%)\left(F_{3,7}=3.8, p=0.07\right)$. Percentages were $9 \%$ for mixed oak-pine and $16 \%$ for cove hardwood. Nitrifier denitrification also differed by site, with the greatest rates occurring in northern hardwood compared with cove hardwood and mixed oak-pine; rates in mixed oak were greater than mixed oak-pine $\left(F_{3,8}=19.2, p<0.05\right)$. Nitrous oxide flux was greatest in soils from northern hardwood, while measurements from all other sites were below detection. Initial $\mathrm{KCl}$ extractable $\mathrm{NO}_{3}{ }^{-}$and $\mathrm{NH}_{4}{ }^{+}$ ranged from 0.77 to $5.6 \mu \mathrm{g} \mathrm{N} \mathrm{g} \mathrm{soil}{ }^{-1}$ (Table 4). 
Table 3. Gross nitrogen cycling measured on $0-10 \mathrm{~cm}$ soils in May 2012. Gross rate units are presented in $\mu \mathrm{g} \mathrm{N} \mathrm{g}_{\text {soil }}{ }^{-1} \mathrm{~h}^{-1}$ and include mineralization, nitrification, dissimilatory nitrate reduction to ammonium (DNRA), nitrifier denitrification, and $\mathrm{N}_{2} \mathrm{O}\left(\times 10^{-3}\right)$.

\begin{tabular}{cccccc}
\hline Site & Mineralization & Nitrification & DNRA & Nitrifier Denitrification & $\mathbf{N}_{\mathbf{2}} \mathbf{O}\left(\times \mathbf{1 0}^{\mathbf{- 3}}\right)$ \\
\hline $\mathrm{OP}$ & $0.55 \pm 0.33 \mathrm{~b}$ & $0.11 \pm 0.04 \mathrm{~b}$ & $0.01 \pm 0.00 \mathrm{~b}$ & $0.75 \pm 0.10 \mathrm{~b}$ & $0.0 \pm 0.0 \mathrm{~b}$ \\
$\mathrm{CH}$ & $2.15 \pm 0.39 \mathrm{ab}$ & $0.19 \pm 0.08 \mathrm{~b}$ & $0.03 \pm 0.02 \mathrm{ab}$ & $0.97 \pm 0.05 \mathrm{~b}$ & $0.0 \pm 0.0 \mathrm{~b}$ \\
$\mathrm{MO}$ & $0.95 \pm 0.41 \mathrm{~b}$ & $0.10 \pm 0.07 \mathrm{~b}$ & $0.02 \pm 0.02 \mathrm{ab}$ & $1.71 \pm 0.22 \mathrm{a}$ & $0.0 \pm 0.0 \mathrm{~b}$ \\
$\mathrm{NH}$ & $7.85 \pm 1.34 \mathrm{a}$ & $3.38 \pm 1.07 \mathrm{a}$ & $0.07 \pm 0.03 \mathrm{a}$ & $2.5 \pm 0.27 \mathrm{a}$ & $1.8 \pm 0.42 \mathrm{a}$ \\
\hline
\end{tabular}

Site abbreviations: $\mathrm{OP}=$ mixed oak-pine; $\mathrm{CH}$ = cove hardwood; $\mathrm{MO}=$ mixed oak; $\mathrm{NH}$ = northern hardwood. Error is indicated by standard error of the mean. Different letters indicate significant differences among sites at $p<0.1$.
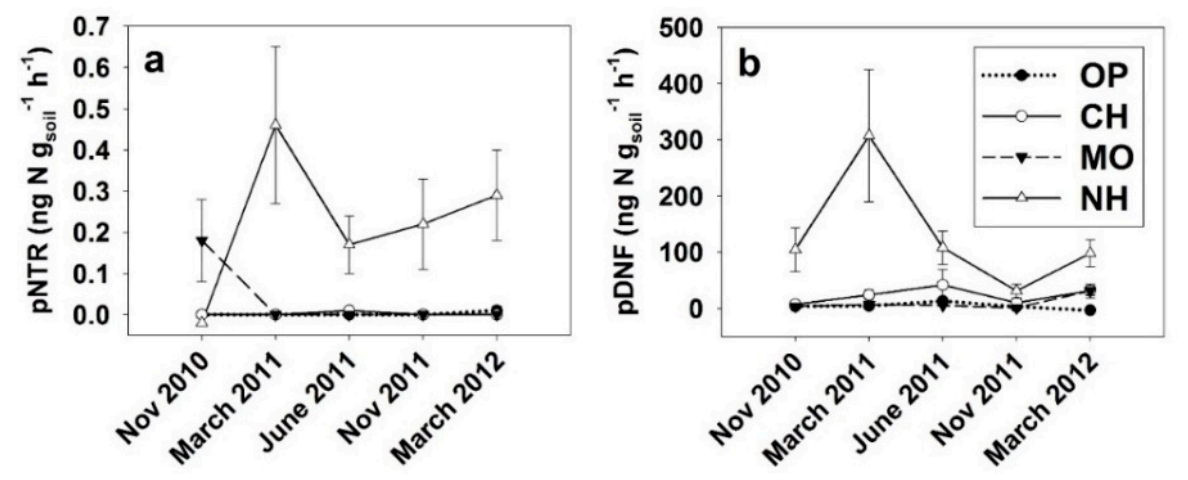

Figure 2. Potential nitrification (pNTR) (a) and potential denitrification (pDNF) (b) rates for the forest floor and the top $15 \mathrm{~cm}$ mineral soil for the different sites. $\mathrm{OP}=$ mixed oak-pine; $\mathrm{CH}=$ cove hardwood; $\mathrm{MO}=$ mixed oak; $\mathrm{NH}=$ northern hardwood.

Table 4. May 2012 assessments of nutrient concentrations, initial microbial biomass (MB), initial microbial biomass $\mathrm{N}(\mathrm{MBN}), \mathrm{C}$ mineralization rates $\left(\mathrm{C}_{\mathrm{min}}\right)$, and average potential nitrification $(\mathrm{pNTR})$ and potential denitrification (pDNF) rates between November 2010 and March 2012.

\begin{tabular}{|c|c|c|c|c|c|c|c|c|}
\hline Site & $\begin{array}{c}\mathrm{NH}_{4}{ }^{+} \\
\left(\mu \mathrm{g} \mathrm{N} \mathrm{g}^{-1}\right) \\
\end{array}$ & $\begin{array}{c}\mathrm{NO}_{3}^{-} \\
\left(\mu \mathrm{g} \mathrm{N} \mathrm{g}^{-1}\right) \\
\end{array}$ & $\begin{array}{c}\mathrm{MB} \\
\left(\mu \mathrm{g} \mathrm{C}^{-1}\right)\end{array}$ & $\begin{array}{c}\text { MBN } \\
\left(\mu \mathrm{g} \mathrm{N} \mathrm{g}^{-1}\right)\end{array}$ & $\begin{array}{c}\mathrm{C}_{\min } \text { oxic } \\
\left(\mu \mathrm{gC} \mathrm{g}^{-1} \mathrm{~d}^{-1}\right)\end{array}$ & $\begin{array}{c}\mathrm{C}_{\min } \text { anoxic } \\
\left(\mu \mathrm{g} \mathrm{C}^{-1} \mathrm{~d}^{-1}\right)\end{array}$ & $\begin{array}{c}\text { pNTR } \\
\left.\text { (ng g }_{\text {soil }}^{-1} h^{-1}\right) \\
\end{array}$ & $\begin{array}{c}\mathrm{pDNF} \\
\left(\mathrm{ng} \mathrm{g}_{\text {soil }}^{-1} \mathrm{~h}^{-1}\right)\end{array}$ \\
\hline $\mathrm{OP}$ & $0.79 \pm 0.03(3) \mathrm{c}+$ & $1.26 \pm 0.43(3) b$ & $287 \pm 69(3)$ & $127 \pm 16(4) b$ & $239 \pm 106(3) b$ & $155 \pm 38(3) b$ & $0.0 \pm 0.0$ & $4.6 \pm 1.4 \mathrm{~b}$ \\
\hline $\mathrm{CH}$ & $1.31 \pm 0.04(3) \mathrm{b}+$ & $1.01 \pm 0.06(3) b$ & $499 \pm 164$ & $224 \pm 17(3) \mathrm{a}$ & $262 \pm 26(3) b$ & $117 \pm 12(3) b$ & $0.0 \pm 0.0$ & $21.3 \pm 7.3 \mathrm{~b}$ \\
\hline MO & $0.77 \pm 0.00(3) \mathrm{c}+$ & $0.67 \pm 0.05(3) b$ & $538 \pm 45(3)$ & $215 \pm 20(4) \mathrm{a}$ & $455 \pm 41(3) a b$ & $196 \pm 8(3) a b$ & $0.0 \pm 0.0$ & $3.8 \pm 0.8 \mathrm{~b}$ \\
\hline NH & $5.6 \pm 0.23(3) \mathrm{a}+$ & $5.4 \pm 0.44(3) \mathrm{a}$ & $634 \pm 57(3)$ & $286 \pm 22(4) a$ & $632 \pm 33(2) a$ & $297 \pm 30(2) a$ & $0.26 \pm 0.07$ & $147.2 \pm 36.8 \mathrm{a}$ \\
\hline
\end{tabular}

Potential nitrification and denitrification rates varied from 0 to 0.46 and 0 to $307 \mathrm{ng} \mathrm{g}_{\text {soil }}{ }^{-1} \mathrm{~h}^{-1}$, respectively (Figure 2). Mean potential nitrification rates did not differ among sites, while mean potential denitrification rates were significantly greater in northern hardwood than in all other sites, with no significant differences among the other sites (Table 4). The averages along all sampling times (Table 4) showed that the northern hardwood site exhibited greater rates than any of the other sites.

\subsection{Microbial Biomass and C Lability}

Microbial biomass $\mathrm{C}$ did not differ among sites; however, the microbial biomass $\mathrm{N}$ was significantly lower in mixed oak-pine compared with the other sites $\left(F_{3,12}=12.3, p<0.001\right.$; Table 4$)$. C mineralization rates (Table 4$)$ differed significantly by site $\left(F_{3,14}=11.7, p<0.001\right)$ and were greater in northern hardwood soils compared with cove hardwood and mixed oak-pine $(p<0.001)$. Potential $\mathrm{C}$ mineralization rates were greater under oxic conditions $\left(F_{1,14}=33.3, p<0.0001\right)$ for all sites. Interaction between site and redox treatment was not significant. 


\subsection{Drivers of Gross Nitrogen Cycling}

We used potential denitrification and carbon mineralization rates to explain the variance in the gross nitrogen cycling processes we measured (Table 5). Potential denitrification rates were positively related to gross $\mathrm{N}$ mineralization, nitrification, nitrifier denitrification, and DNRA rates (Table 5). Oxic carbon mineralization rates were positively correlated with DNRA and nitrifier denitrification. Anoxic carbon lability estimates were correlated with nitrifier denitrification. The northern hardwood system was an outlier in many analyses and excluding this site from statistical analyses revealed that labile carbon was negatively correlated with $\mathrm{N}_{2} \mathrm{O}$ production (Table 5). $\mathrm{N}$ mineralization was positively correlated to gross nitrification rates, nitrifier denitrification, and DNRA (Table 6). Gross nitrification rates were positively correlated with nitrifier denitrification (Table 6).

Table 5. Spearman's correlation coefficients between gross nitrogen cycling rates and edaphic characteristics (carbon mineralization rates $\left(\mathrm{C}_{\min }\right)$ incubated under oxic or anoxic conditions and potential denitrification).

\begin{tabular}{|c|c|c|c|c|c|c|c|c|c|c|}
\hline \multirow{2}{*}{$\begin{array}{l}\text { Explanatory } \\
\text { Variable }\end{array}$} & \multicolumn{2}{|c|}{ N Mineralization } & \multicolumn{2}{|c|}{ Nitrification } & \multicolumn{2}{|c|}{ DNRA } & \multicolumn{2}{|c|}{ Nitrifier Denitrification } & \multicolumn{2}{|c|}{$\mathrm{N}_{2} \mathrm{O}$} \\
\hline & All & Excl NH & All & Excl NH & All & Excl NH & All & Excl NH & All & Excl NH \\
\hline $\mathrm{C}_{\min }$ oxic & 0.27 & -0.32 & -0.02 & -0.40 & $0.55+$ & 0.17 & $0.82 * *$ & $0.68 *$ & 0.18 & $-0.71+$ \\
\hline $\mathrm{C}_{\min }$ anoxic & 0.28 & -0.32 & 0.03 & -0.33 & 0.39 & -0.10 & $0.66^{*}$ & 0.38 & 0.22 & $-0.68+$ \\
\hline pDNF & $0.94 * *$ & $0.87 * *$ & $0.60 t$ & 0.27 & $0.69 *$ & 0.53 & $0.72 * *$ & 0.35 & $0.64 *$ & 0.04 \\
\hline
\end{tabular}

All sites included in analyses "All" and northern hardwood site is excluded from analysis in "Excl NH". DNRA = dissimilatory nitrate reduction to ammonium; $\mathrm{C}_{\min }=$ carbon mineralization; $\mathrm{pDNF}=$ potential denitrification; $\mathrm{N}_{2} \mathrm{O}-\mathrm{NH}_{4}{ }^{+}=\mathrm{N}_{2} \mathrm{O}$ fluxes in $\mathrm{NH}_{4}{ }^{+}$-labeled soils; $\mathrm{N}_{2} \mathrm{O}-\mathrm{NH}_{4}{ }^{+}=\mathrm{N}_{2} \mathrm{O}$ fluxes in $\mathrm{NH}_{4}{ }^{+}$-labeled soils. Sample number was between 9 and 12 for the All analysis and 7 and 9 for the Excl NH analysis. Correlations in bold highlight significant relationships. ${ }^{* *} p<0.01,{ }^{*} p<0.05,+p<0.1$.

Table 6. Pearson's correlation coefficients between gross nitrogen cycling processes.

\begin{tabular}{|c|c|c|c|c|c|}
\hline & N Mineralization & Nitrification & DNRA & Nitrifier Denitrification & $\mathbf{N}_{2} \mathrm{O} \ddagger$ \\
\hline $\mathrm{N}$ mineralization & & $0.70(11) *$ & $0.61(12) *$ & $0.64(12) *$ & $0.60(10)+$ \\
\hline Nitrification & & & $0.47(11) \dagger$ & $0.67(11)$ * & $0.72(9)$ * \\
\hline DNRA & & & & $0.54(12)+$ & $0.62(10)+$ \\
\hline Nitr. Denitr. & & & & & $0.59(12) t$ \\
\hline $\mathrm{N}_{2} \mathrm{O}-\mathrm{NH}_{4}{ }^{+}$ & & & & & \\
\hline
\end{tabular}

DNRA $=$ dissimilatory nitrate reduction to ammonium. The sample number is in parentheses. ${ }^{*} p<0.05,+p<0.1$. $\ddagger$ Spearman correlation coefficient (rho) used due to non-normal distribution $\mathrm{N}_{2} \mathrm{O}$ fluxes.

\section{Discussion}

This study focused on elucidating how potential and gross rates of soil $\mathrm{N}$ transformations differ among representative sites in the southern Appalachian Mountains and with microbial biomass $\mathrm{C}$ and $\mathrm{N}$ and soil $\mathrm{C}$ availability. We measured high potential denitrification rates in these well-aerated soils along with significant rates of nitrifier denitrification, both of which result in soil $\mathrm{N}_{2}$ gas emissions. We also found that while DNRA rates were low, this pathway may result in significant nitrogen retention in the mixed-oak site.

\subsection{Nitrogen Mineralization and Nitrification}

The rates of gross $\mathrm{N}$ mineralization and nitrification in this study exhibited similar patterns to net transformation rates determined on these sites between 1992 and 2010 using the closed core in situ incubation method $[14,15,52]$. The proportion of mineralized $\mathrm{N}$ that was subsequently nitrified was also similar for both net and gross measurements in the cove hardwood (net $=11 \%$; gross $=9 \%$ ), mixed-oak (net $=14 \%$; gross $=10 \%$ ), and northern hardwood (net $=50 \%$; gross $=50 \%$ ) sites. However, the fraction of $\mathrm{N}$ nitrified in the low-N mixed-oak-pine site was substantially greater when measured using gross methods (20\%) compared with net (9\%) [15]. This is similar to the findings of Hart et al. [53] and suggests that net mineralization and nitrification rates can be poor predictors of the mechanisms 
regulating gross nitrogen cycling dynamics. Our data suggest we should be cautious when using net rates to parameterize mechanistic nitrogen cycling models, especially in low- $\mathrm{N}$ sites.

\subsection{Gaseous Nitrogen Losses}

The reduction of nitrate to $\mathrm{N}_{2}$ via nitrifier denitrification proved to be a potentially important process in all sites. We measured greater nitrifier denitrification in the high-elevation sites (mixed oak and northern hardwood) than in the low-elevation sites (oak-pine and cove hardwood). Nitrifier denitrification could be responsible for the release of $\mathrm{N}_{2}$ or it could be the product of the anammox pathway $[34,54]$, but the current experimental design could not distinguish between the two processes. However, Davies et al. (unpublished data) measured gross anammox and denitrification in the mixed-oak site in the Coweeta basin, and their data suggested that anammox contributed $<5.7 \%$ of the $\mathrm{N}_{2}$ produced during nitrate reduction, suggesting that nitrifier denitrification is, in fact, the likely dominant pathway for $\mathrm{N}_{2}$ formation from $\mathrm{NH}_{4}$. We found little accumulation of labeled nitrate during measurement of gross nitrifier denitrification, suggesting that, in situ, this process reduces $\mathrm{NO}_{3}$ with a final product of $\mathrm{N}_{2}$, as posited by Wrage et al. [55]. For example, in the mixed-oak site, which had high nitrifier denitrification rates, potential denitrification rates were not high, suggesting that $\mathrm{N}_{2}$ was produced from $\mathrm{NH}_{4}$ and it was unlikely to be the product of a coupled nitrification-denitrification pathway.

\subsection{Nitrogen Retention by DNRA}

Inorganic nitrogen retention, calculated as the ratio of gross DNRA to gross nitrification, is an important process in moist tropical forests $[45,56]$, yet it has rarely been considered in temperate ecosystems [57]. We detected DNRA in all sites, similar to a study conducted in nonsaturated temperate zone soils by [11]. Our data suggest that in mixed-oak ecosystems, often characterized by low nitrification rates, DNRA could be a crucial nitrogen retention pathway. DNRA could reduce up to $20 \%$ of the $\mathrm{NO}_{3}$ produced during nitrification back to $\mathrm{NH}_{4}$, preventing loss by either denitrification or leaching. We measured significant rates of gross ${ }^{15} \mathrm{NO}_{3}$ reduction, which could also occur via ANRA. On the other hand, we observed no change in microbial biomass ${ }^{15} \mathrm{~N}$ during the incubation, making ANRA less likely [58].

\subsection{Drivers of Soil Nitrogen Cycling}

We examined the relationships between gross and net $\mathrm{N}$ transformation processes to discern the primary drivers of soil $\mathrm{N}$ cycling. This information is timely, as $\mathrm{N}$ deposition across the southeastern United States has shifted from being dominated by $\mathrm{NO}_{3}$ to $\mathrm{NH}_{4}$ forms of nitrogen $[59,60]$. It is likely that greater ammonium availability would enhance nitrifier denitrification $\mathrm{N}_{2} \mathrm{O}$ emissions in the aerated soils of the southern Appalachian Mountains [61]. Gross nitrifier denitrification was correlated with both potential denitrification and labile carbon commonly released from root exudates, shown to increase nitrifier denitrification and fluxes of $\mathrm{N}_{2}$ and $\mathrm{N}_{2} \mathrm{O}$ [62].

Research conducted by Brumme et al. [63] and Groffman et al. [64] in forest ecosystems that were historically exposed to high $\mathrm{N}$ deposition in Germany and the northeastern United States has suggested that soils high in organic matter yield the greatest $\mathrm{N}_{2} \mathrm{O}$ fluxes. Their data suggest that $\mathrm{N}_{2} \mathrm{O}$ fluxes will increase as soil inorganic $\mathrm{N}$ concentrations increase. Our data from the northern hardwood forest support this finding, where we found high potential $\mathrm{N}_{2} \mathrm{O}$ fluxes in the soils with high total organic matter and nitrate concentrations [14]. Additionally, we found that $\mathrm{N}_{2} \mathrm{O}$ production was negatively correlated with labile carbon in $\mathrm{NH}_{4}$-amended incubations. The positive correlation between labile $\mathrm{C}$ and denitrification suggests that increasing carbon availability in N-rich ecosystems would increase $\mathrm{N}_{2} \mathrm{O}$ emissions due to nitrifier denitrification. This process is positively correlated with $\mathrm{N}_{2} \mathrm{O}$ fluxes in the $\mathrm{NH}_{4}$-labeled soils, making this the most likely process responsible for $\mathrm{N}_{2} \mathrm{O}$ production in the high $\mathrm{N}$ sites. Similar to other studies $[63,64]$, we found that sites characterized by an abundance of both available nitrate and labile carbon are likely to exhibit high $\mathrm{N}_{2} \mathrm{O}$ emissions. 


\section{Conclusions}

Gross rates of $\mathrm{N}$ transformations, such as mineralization and nitrification, determined in the laboratory varied among sites and were not always similar to net rates determined in situ. Nitrate reduction by nitrifier denitrification produced gaseous $\mathrm{N}$ as both $\mathrm{N}_{2}$ and $\mathrm{N}_{2} \mathrm{O}$ at rates not previously measured in these well-aerated soils, suggesting that this process may be relevant in the environmental conditions of the southern Appalachians. Our data suggest that DNRA plays an important role in $\mathrm{N}$ retention in the mixed-oak site, which exhibited low $\mathrm{NO}_{3}$ and $\mathrm{NH}_{4}$ availability and a relatively high ratio of DNRA to nitrification. While the role of $\mathrm{N}_{2} \mathrm{O}$ emissions under future deposition and climate scenarios remains unclear, we suggest that the mixed-oak and northern hardwood forest sites appear to have the greatest potential for increased emissions from the well-aerated soil of the southern Appalachian Mountains. Future regional studies are critically needed to confirm how widespread these novel findings are across this region and its implications for biogeochemical and climate change models.

Author Contributions: Conceptualization, P.B.; methodology, P.B., J.D.K.; data analysis, P.B.; investigation, P.B., writing_original draft preparation, P.B.; writing_review and editing, J.D.K. and J.E.M.; project administration, P.B.; funding acquisition, J.D.K. and J.E.M.

Funding: This research was supported by the National Science Foundation for the Coweeta LTER (DEB0218001 and DEB0823293) and USDA Forest Service, Southern Research Station, Coweeta Hydrologic Laboratory project funds.

Acknowledgments: We thank Megan Machmuller and Jeremy Sullivan for assistance in the laboratory and the field. Comments and edits from Charles Cowden and Paul Frankson greatly improved this manuscript. Chemical analyses were conducted at the Coweeta Hydrologic Laboratory Analytical Lab and isotopic analyses at the University of California, Davis Isotope Facility.

Conflicts of Interest: The authors declare no conflict of interest.

\section{References}

1. Cai, M.; Schwartz, J.S.; Robinson, R.B.; Moore, S.E.; Kulp, M.A. Long-term annual and seasonal patterns of acidic deposition and stream water quality in a Great Smoky Mountains high-elevation watershed. Water Air Soil Pollut. 2011, 219, 547-562. [CrossRef]

2. Fowler, D.; Coyle, M.; Skiba, U.; Sutton, M.A.; Cape, J.N.; Reis, S.; Sheppard, L.J.; Jenkins, A.; Grizzetti, B.; Galloway, J.N.; et al. The global nitrogen cycle in the twenty-first century. Philos. Trans. R. Soc. B Biol. Sci. 2013, 368, 20130164. [CrossRef] [PubMed]

3. Gruber, N.; Galloway, J.N. An Earth-system perspective of the global nitrogen cycle. Nature 2008, 451, 293. [CrossRef] [PubMed]

4. Brookshire, E.; Gerber, S.; Webster, J.R.; Vose, J.M.; Swank, W.T. Direct effects of temperature on forest nitrogen cycling revealed through analysis of long-term watershed records. Glob. Chang. Biol. 2010, 17, 297-308. [CrossRef]

5. Melillo, J.M.; Steudler, P.A.; Aber, J.D.; Newkirk, K.; Lux, H.; Bowles, F.P.; Catricala, C.; Magill, A.; Ahrens, T.; Morrisseau, S. Soil warming and carbon-cycle feedbacks to the climate system. Science 2002, 298, 2173-2176. [CrossRef]

6. Churkina, G.; Brovkin, V.; von Bloh, W.; Trusilova, K.; Jung, M.; Dentener, F. Synergy of rising nitrogen depositions and atmospheric $\mathrm{CO}_{2}$ on land carbon uptake moderately offsets global warming. Glob. Biogeochem. Cycles 2009, 23. [CrossRef]

7. De Vries, W. Assessment of the relative importance of nitrogen deposition and climate change on the sequestration of carbon by forests in Europe: An overview. For. Ecol. Manag. 2009, 258, vii-x. [CrossRef]

8. Bolstad, P.V.; Vose, J.M.; McNulty, S.G. Forest productivity, leaf area, and terrain in southern Appalachian deciduous forests. For. Sci. 2001, 47, 419-427.

9. Hofmockel, K.S.; Zak, D.R.; Moran, K.K.; Jastrow, J.D. Changes in forest soil organic matter pools after a decade of elevated $\mathrm{CO}_{2}$ and $\mathrm{O}_{3}$. Soil Biol. Biochem. 2011, 43, 1518-1527. [CrossRef]

10. Zaehle, S.; Ciais, P.; Friend, A.D.; Prieur, V. Carbon benefits of anthropogenic reactive nitrogen offset by nitrous oxide emissions. Nat. Geosci. 2011, 4, 601-605. [CrossRef]

11. Yang, W.H.I. Quantification of and Controls on Dinitrogen and Nitrous Oxide Fluxes from Terrestrial Ecosystems. Ph.D. Thesis, University of California, Berkeley, CA, USA, 2010. 
12. Keeney, D.R. Prediction of soil nitrogen availability in forest ecosystems: A literature review. For. Sci. 1980, 26, 159-171.

13. Reich, P.B.; Grigal, D.F.; Aber, J.D.; Gower, S.T. Nitrogen mineralization and productivity in 50 hardwood and conifer stands on diverse soils. Ecology 1997, 78, 335-347. [CrossRef]

14. Knoepp, J.; Vose, J.; Swank, W. Nitrogen deposition and cycling across an elevation and vegetation gradient in southern Appalachian forests. Int. J. Environ. Stud. 2008, 65, 391-410. [CrossRef]

15. Knoepp, J.D.; Swank, W.T. Rates of nitrogen mineralization across an elevation and vegetation gradient in the southern Appalachians. Plant Soil 1998, 204, 235-241. [CrossRef]

16. Knoepp, J.D.; See, C.R.; Vose, J.M.; Miniat, C.F.; Clark, J.S. Total C and N Pools and Fluxes Vary with Time, Soil Temperature, and Moisture Along an Elevation, Precipitation, and Vegetation Gradient in Southern Appalachian Forests. Ecosystems 2018, 21, 1623-1638. [CrossRef]

17. Koch, O.; Tscherko, D.; Kandeler, E. Temperature sensitivity of microbial respiration, nitrogen mineralization, and potential soil enzyme activities in organic alpine soils. Glob. Biogeochem. Cycles 2007, 21. [CrossRef]

18. Bouwman, A.F.; Beusen, A.H.W.; Griffioen, J.; van Groenigen, J.W.; Hefting, M.M.; Oenema, O.; van Puijenbroek, P.J.T.M.; Seitzinger, S.; Slomp, C.P.; Stehfest, E. Global trends and uncertainties in terrestrial denitrification and $\mathrm{N}_{2} \mathrm{O}$ emissions. Philos. Trans. R. Soc. B Biol. Sci. 2013, 368, 20130112. [CrossRef]

19. Groffman, P.; Butterbach-Bahl, K.; Fulweiler, R.; Gold, A.; Morse, J.; Stander, E.; Tague, C.; Tonitto, C.; Vidon, P. Challenges to incorporating spatially and temporally explicit phenomena (hotspots and hot moments) in denitrification models. Biogeochemistry 2009, 93, 49-77. [CrossRef]

20. Seitzinger, S.; Harrison, J.; Böhlke, J.; Bouwman, A.; Lowrance, R.; Peterson, B.; Tobias, C.; Drecht, G. Denitrification across landscapes and waterscapes: A synthesis. Ecol. Appl. 2006, 16, 2064-2090. [CrossRef]

21. Bonito, G.M.; Coleman, D.C.; Haines, B.L.; Cabrera, M.L. Can nitrogen budgets explain differences in soil nitrogen mineralization rates of forest stands along an elevation gradient? For. Ecol. Manag. 2003, 176, 563-574. [CrossRef]

22. Schlesinger, W.H.; Bernhardt, E.S. Biogeochemistry: An Analysis of Global Change; Academic Press: Cambridge, MA, USA, 2013.

23. Tiedje, J. Ecology of denitrification and dissimilatory nitrate reduction to ammonium. Biol. Anaerob. Microorg. 1988, 179, 244.

24. Cole, J. Assimilatory and dissimilatory reduction of nitrate to ammonia. In The Nitrogen and Sulphur Cycles; Cambridge University Press: Cambridge, UK, 1988; pp. 281-329.

25. Davidson, E. Sources of nitric oxide and nitrous oxide following wetting of dry soil. Soil Sci. Soc. Am. J. 1992, 56, 95-102. [CrossRef]

26. Verchot, L.; Holmes, Z.; Mulon, L.; Groffman, P.; Lovett, G. Gross vs net rates of N mineralization and nitrification as indicators of functional differences between forest types. Soil Biol. Biochem. 2001, 33, 1889-1901. [CrossRef]

27. Pett-Ridge, J.; Silver, W.; Firestone, M. Redox Fluctuations Frame Microbial Community Impacts on N-cycling Rates in a Humid Tropical Forest Soil. Biogeochemistry 2006, 81, 95-110. [CrossRef]

28. Morley, N.; Baggs, E.M. Carbon and oxygen controls on $\mathrm{N}_{2} \mathrm{O}$ and $\mathrm{N}_{2}$ production during nitrate reduction. Soil Biol. Biochem. 2010, 42, 1864-1871. [CrossRef]

29. Parkin, T. Soil microsites as a source of denitrification variability. Soil Sci Soc. Am. J. 1987, 51, 1194-1199. [CrossRef]

30. Sexstone, A.; Revsbech, N.; Parkin, T.; Tiedje, J. Direct measurement of oxygen profiles and denitrification rates in soil aggregates. Soil Sci Soc. Am. J. 1985, 49, 645-651. [CrossRef]

31. Baas, P.; Knoepp, J.D.; Markewitz, D.; Mohan, J.E. Areas of residential development in the southern Appalachian Mountains are characterized by low riparian zone nitrogen cycling and no increase in soil greenhouse gas emissions. Biogeochemistry 2017, 133, 113-125. [CrossRef]

32. Baas, P.; Markewitz, D.; Knoepp, J.D.; Mohan, J.E. Nitrogen cycling heterogeneity: An approach for plot scale assessments. Soil Sci. Soc. Am. J. 2014, 78, S237-S247. [CrossRef]

33. McClain, M.E.; Boyer, E.W.; Dent, C.L.; Gergel, S.E.; Grimm, N.B.; Groffman, P.M.; Hart, S.C.; Harvey, J.W.; Johnston, C.A.; Mayorga, E.; et al. Biogeochemical hot spots and hot moments at the interface of terrestrial and aquatic ecosystems. Ecosystems 2003, 6, 301-312. [CrossRef]

34. Brandes, J.A.; Devol, A.H.; Deutsch, C. New Developments in the Marine Nitrogen Cycle. Chem. Rev. 2007, 107, 577-589. [CrossRef] [PubMed] 
35. Laseter, S.H.; Ford, C.R.; Vose, J.M.; Swift, L.W. Long-term temperature and precipitation trends at the Coweeta Hydrologic Laboratory, Otto, North Carolina, USA. Hydrol. Res. 2012, 43, 890-901. [CrossRef]

36. Swift, J.L.W.; Cunningham, G.B. Climatology and Hydrology. In Forest Hydrology and Ecology at Coweeta; Swank, W.T., Crossley, D.A., Jr., Eds.; Springer-Verlag: New York, NY, USA, 1988; Volume 66, p. 469.

37. Elliott, K.J.; Swank, W.T. Long-term changes in forest composition and diversity following early logging (1919-1923) and the decline of American chestnut (Castanea dentata). Plant Ecol. 2008, 197, 155-172. [CrossRef]

38. Turner, M.G.; Pearson, S.M.; Bolstad, P.; Wear, D.N. Effects of land-cover change on spatial pattern of forest communities in the Southern Appalachian Mountains (USA). Landsc. Ecol. 2003, 18, 449-464. [CrossRef]

39. Soil Survey Staff; United States Department of Agriculture Natural Resources Conservation Service. Web Soil Survey. 2013. Available online: http://websoilsurvey.nrcs.usda.gov/ (accessed on 5 January 2013).

40. Coweeta Long Term Ecological Research. Available online: http://coweeta.uga.edu/ (accessed on 9 December 2019).

41. Groffman, P.; Altabet, M.; Böhlke, J.; Butterbach-Bahl, K.; David, M.; Firestone, M.; Giblin, A.; Kana, T.; Nielsen, L.; Voytek, M. Methods for measuring denitrification: Diverse approaches to a difficult problem. Ecol. Appl. 2006, 16, 2091-2122. [CrossRef]

42. USEPA. Methods for Chemical Analysis of Water and Waste. Determination of Nitrite/Nitrate by Automated Cadmium Reduction; Method 353.2; Environmental Monitoring and Support Lab., Office of Research and Development, USEPA: Cincinnati, OH, USA, 1983.

43. Groffman, P.; Holland, E.; Myrold, D.; Robertson, G.; XiaoMing, Z.; Coleman, D.; Bledsoe, C.; Sollins, P. Denitrification. In Standard Soil Methods for Long-Term Ecological Research; Robertson, G.P., Coleman, D.C., Bledsoe, C.S., Sollins, P., Eds.; Oxford University: Oxford, UK, 1999; pp. 272-288.

44. Davidson, E.; Hart, S.; Shanks, C.; Firestone, M. Measuring gross nitrogen mineralization, and nitrification by ${ }^{15} \mathrm{~N}$ isotopic pool dilution in intact soil cores. Eur. J. Soil Sci. 1991, 42, 335-349. [CrossRef]

45. Silver, W.; Herman, D.; Firestone, M. Dissimilatory nitrate reduction to ammonium in upland tropical forest soils. Ecology 2001, 82, 2410-2416. [CrossRef]

46. Cabrera, M.L.; Beare, M.H. Alkaline Persulfate Oxidation for Determining Total Nitrogen in Microbial Biomass Extracts. Soil Sci. Soc. Am. J. 1993, 57, 1007-1012. [CrossRef]

47. Bradford, M.A.; Watts, B.W.; Davies, C.A. Thermal adaptation of heterotrophic soil respiration in laboratory microcosms. Glob. Chang. Biol. 2010, 16, 1576-1588. [CrossRef]

48. USEPA. Methods for Chemical Analysis of Water and Waste. Determination of Nitrogen as Ammonia; Method 350.1; Environmental Monitoring and Support Lab., Office of Research and Development, USEPA: Cincinnati, $\mathrm{OH}$, USA, 1983.

49. Kirkham, D.; Bartholomew, W. Equations for following nutrient transformations in soil, utilizing tracer data. Soil Sci. Soc. Am. J. 1954, 18, 33-34. [CrossRef]

50. Beck, T.; Joergensen, R.G.; Kandeler, E.; Makeschin, F.; Nuss, E.; Oberholzer, H.R.; Scheu, S. An inter-laboratory comparison of ten different ways of measuring soil microbial biomass C. Soil Biol. Biochem. 1997, 29, 1023-1032. [CrossRef]

51. Brookes, P.; Landman, A.; Pruden, G.; Jenkinson, D. Chloroform fumigation and the release of soil nitrogen: A rapid direct extraction method to measure microbial biomass nitrogen in soil. Soil Biol. Biochem. 1985, 17, 837-842. [CrossRef]

52. Mclean, K. Past, Present, and Future Soil Nitrogen and Phosphorus Dynamics in Southern Appalachian Forests; University of Georgia: Athens, GA, USA, 2011.

53. Hart, S.C.; Nason, G.E.; Myrold, D.D.; Perry, D.A. Dynamics of gross nitrogen transformations in an old-growth forest: The carbon connection. Ecology 1994, 75, 880-891. [CrossRef]

54. Poth, M.; Focht, D.D. $15 \mathrm{~N}$ kinetic analysis of $\mathrm{N}_{2} \mathrm{O}$ production by Nitrosomonas europaea: An examination of nitrifier denitrification. Appl. Environ. Microbiol. 1985, 49, 1134-1141.

55. Wrage, N.; Velthof, G.; van Beusichem, M.; Oenema, O. Role of nitrifier denitrification in the production of nitrous oxide. Soil Biol. Biochem. 2001, 33, 1723-1732. [CrossRef]

56. Silver, W.L.; Thompson, A.W.; Reich, A.; Ewel, J.J.; Firestone, M.K. Nitrogen Cycling in Tropical Plantation Forests: Potential Controls on Nitrogen Retention. Ecol. Appl. 2005, 15, 1604-1614. [CrossRef]

57. Rütting, T.; Huygens, D.; Müller, C.; van Cleemput, O.; Godoy, R.; Boeckx, P. Functional role of DNRA and nitrite reduction in a pristine south Chilean Nothofagus forest. Biogeochemistry 2008, 90, 243-258. [CrossRef] 
58. Vitousek, P.M.; Matson, P.A. Nitrogen transformations in a range of tropical forest soils. Soil Biol. Biochem. 1988, 20, 361-367. [CrossRef]

59. Li, Y.; Schichtel, B.A.; Walker, J.T.; Schwede, D.B.; Chen, X.; Lehmann, C.M.; Puchalski, M.A.; Gay, D.A.; Collett, J.L. Increasing importance of deposition of reduced nitrogen in the United States. Proc. Natl. Acad. Sci. USA 2016, 113, 5874-5879. [CrossRef]

60. National Atmospheric Deposition Program. National Atmospheric Deposition Program 2016 Annual Summary; NADP Data Report, 2017-01; Illinois State Water Survey: Champaign, IL, USA; University of Illinois at Urbana-Champaign: Urbana, IL, USA, 2017.

61. Zhu, X.; Burger, M.; Doane, T.A.; Horwath, W.R. Ammonia oxidation pathways and nitrifier denitrification are significant sources of $\mathrm{N}_{2} \mathrm{O}$ and $\mathrm{NO}$ under low oxygen availability. Proc. Natl. Acad. Sci. USA 2013, 110, 6328-6333. [CrossRef]

62. Bengtson, P.; Barker, J.; Grayston, S.J. Evidence of a strong coupling between root exudation, C and N availability, and stimulated SOM decomposition caused by rhizosphere priming effects. Ecol. Evol. 2012, 2, 1843-1852. [CrossRef] [PubMed]

63. Brumme, R.; Borken, W.; Finke, S. Hierarchical control on nitrous oxide emission in forest ecosystems. Glob. Biogeochem. Cycles 1999, 13, 1137-1148. [CrossRef]

64. Groffman, P.; Davidson, E.; Seitzinger, S. New approaches to modeling denitrification. Biogeochemistry 2009, 93, 1-5. [CrossRef]

(C) 2019 by the authors. Licensee MDPI, Basel, Switzerland. This article is an open access article distributed under the terms and conditions of the Creative Commons Attribution (CC BY) license (http://creativecommons.org/licenses/by/4.0/). 